\title{
Närvarande mödrar och tillräckligt frånvarande fäder. Om socialtjänstens bedömningar av föräldrars omsorg
}

\author{
GUNILLA PETERSSON
}

\begin{abstract}
Ställer socialtjänsten olika krav på mödrars och fäders föräldraskap i barnavårdsutredningar? Den här artikeln analyserar skillnaderna vid bedömningar av mödrars och fäders omsorg samtidigt som den söker förstå bakgrunden till de skilda bedömningsgrunderna. ${ }^{1}$
\end{abstract}

I svensk såväl som i utländsk forskning kring barnavårdsärenden påtalas en skillnad i bedömningen av mödrar och fäder. Mödrar granskas mer ingående än fäder, och dessutom ställs andra krav på mödrars föräldraskap än på fäders (Lundström 1993, Ericsson 1996, Egelund 1997, Hollander 2001). Flera forskare framhåller också att fäderna är näst intill osynliga i socialtjänstens utredningar. De menar att det finns en mycket stark koppling mellan moder-

Gunilla Petersson, FD Tema kommunikation, lektor i socialt arbete vid institutionen för beteendevetenskap, Linköpings universitet. skap och omsorg och att en diskussion kring sviktande omsorg alltid kommer att handla om mödrar och ett skuldbeläggande av mödrarna (Gordon 1988, Swift 1995, Turney 2000). Turney (2000) ser detta som en feminisering av omsorg och framhåller

1 Projektet har finansierats av HSFR och genomförts inom ramen för forskningsprogrammet "Välfärdsstatens omvandling och en ny barndom« vid tema Barn, Linköpings universitet. Jag vill här tacka deltagarna i detta forskningsprogram och i forskarseminariet "Sociala gruppen" vid Tema och IBV, Linköpings universitet samt två anonyma granskare, för värdefulla synpunkter. 
att omsorgssvikt därför bör studeras som ett könsbundet problem. Swift (1995) är inne på samma linje. Hon menar att bedömningar av omsorg alltid utgår från en bild av kärnfamiljen där far arbetar och mor ägnar sig åt hem och barn, och att utredningar av omsorgssvikt därför alltid kommer att uppehålla sig vid mödrars agerande och relation till barnen. En annan förklaring till det fokus som finns på mödrar och moderskap anser hon vara det sociala arbetets kunskapsbas och då framförallt det psykologiska synsättet som huvudsakligen inriktar sig på relationen mellan mor och barn.

Skillnaden i socialarbetares bedömningar av mödrar och fäder är således väl belagd i tidigare forskning. En förklaring till det fokus som finns på mödrar i socialtjänstens utredningar är att det oftast är de som har ansvar för barnen. Även om det i Sverige är vanligt med gemensam vårdnad bor de barn som blir föremål för utredningar ofta med modern som ensam biologisk förälder (Sundell \& Karlsson 1999). Detta innebär att socialtjänstens insatser koncentreras på mödrarna (Sundell \& Alldahl 1993). Men det har också bidragit till att den forskning som finns om föräldrars omsorgssvikt har kommit att koncentreras på mödrarna och deras relation till barnen, om fäders föräldraskap berörs är det sällan deras omsorgsbrist som står i fokus (jfr. Turney 2000). Ett undantag är Bangura Arvidssons studie av ifrågasatta fäder (2003) vilken behandlar just fäder som har kontakt med socialtjänsten. Hon menar att fäderna inte alls är osynliga i utredningarna, men påpekar samtidigt att de uppgifter som finns ofta är fragmentariska. Hennes slutsats blir därför att faderns föräldraskap i första hand fram- ställs som att han rycker in som assistent när moderns omsorg brister.

Den här artikeln tar fasta på skillnaden i socialtjänstens bedömningar av mödrar och fäder i deras omsorg om barnen. Studien utgår från en detaljerad analys av vad som skrivs om mödrar och fäder i barnavårdsutredningar. Syftet är att analysera utifrån vilka kunskapsramar och vilken syn på föräldraskap och omsorg som mödrar och fäder bedöms. Dessutom vill jag diskutera hur mödrar och fäder enligt utredningarna sägs agera och vilka konsekvenser deras agerande har för bedömningen av dem själva.

För att kunna avtäcka hur mödrar och fäder framställs som föräldrar och klienter i utredningarna, liksom vilka utgångspunkter som används för att bedöma den goda respektive sviktande omsorgen, tar studien sin utgångspunkt i socialkonstruktionismen. Det teoretiska perspektivet kan lätttast beskrivas med vad Loseke (1999) kallar begränsad eller kontextbunden konstruktionism. Liknande teoretiska utgångspunkter har till exempel använts av Swift (1995), Egelund (1997), Parton et al. (1997) och Bangura Arvidsson (2003). Enkelt uttryckt innebär perspektivet att jag utgår från att sociala problem inte är entydiga och givna fenomen, utan att de konstrueras inom de praktiker i vilka de behandlas. I socialtjänstens utredningar konstrueras både barnens behov och föräldrarnas prestationer. Dessa konstruktioner är givetvis beroende av både övergripande och intilliggande diskurser, så som psykologiska teorier samt synen på familjen och på barn och barndom.

En annan viktig utgångspunkt inom socialkonstruktionismen är hur man förhåller sig till det material som studeras - i det 
här fallet socialtjänstens utredningstexter. Utredningarna ses som texter vilka producerats i ett speciellt syfte, nämligen för att övertyga beslutsfattarna om att ett omhändertagande av barnet/barnen är nödvändigt. De ses som texter vilka skrivits för att legitimera en viss bestämd åtgärd (Lundström 1993, Hilte 2000, Egelund 2003).

\section{Metod}

Undersökningens material består av alla utredningar gällande placeringar av barn i åldrarna 7-14 år under året 1998 inom en kommun. Den aktuella kommunen har drygt 100000 invånare. I materialet för studien ingår 26 ärenden. ${ }^{2} 16$ ärenden har beslutats enligt Socialtjänstlagen (SoL) och placeringen av barnen har således skett med föräldrarnas samtycke, tio ärenden har beslutats enligt Lagen med särskilda bestämmelser om vård av unga (LVU) och placeringen har i dessa skett utan föräldrarnas medgivande. Samtliga ärenden beslutades i enlighet med den utredande tjänstemannens förslag om åtgärd. SoL-ärendena beslutas av Socialnämndens behandlingsutskott medan LVU-ärendena beslutas av Länsrätten. Alla ärenden utom ett är så kallade miljöfall, d v s att barnet omhändertas på grund av problem i hemmiljön. Endast ett ärende kan hänföras till kategorin beteendefall, $\mathrm{d} v \mathrm{~s}$ att barnet omhändertas på grund av sitt eget beteende. Av miljöärendena görs alla omhändertaganden,

2 I materialet fanns egentligen 27 ärenden men då båda föräldrarna saknas i ett ärende har detta här utelämnats ur analysen. utom två som gäller misshandel, med hänvisning till föräldrarnas bristande omsorg om barnen.

Ärendena omfattar 35 barn, 18 flickor och 17 pojkar. Fem av barnen är yngre än 7 år, men de finns med i utredningar tillsammans med äldre syskon som faller inom den utvalda åldersgruppen och har därför tagits med i studien. Av barnen har 20 placerats enligt SoL och 15 enligt LVU. Vad gäller social bakgrund har alla familjer utom två tidigare haft kontakt med socialtjänsten och föräldrarnas förankring på arbetsmarknaden är genomgående svag. I 13 ärenden finns anteckningar om att den förälder som barnet bott hos har missbruksproblem, i åtta ärenden finns psykisk ohälsa i bakgrunden och i tre ärenden har föräldrarna något funktionshinder. ${ }^{3}$ De karakteristika som här givits av barnens sociala bakgrund samt orsakerna till omhändertagande stämmer väl med resultat från tidigare forskning om barnavårdsärenden (jfr. Lundström 1993, Sundell \& Karlsson 1999).

Vid analysen har allt som nämnts om mödrar respektive fäder först kodats var för sig för att därefter ingå i en jämförande analys. I första hand är analysen kvalitativ, d v s ägnad att söka efter utfallsrummet av olikheter i beskrivningar och bedömningar, men vissa kvantifieringar har gjorts för att lyfta fram tendenser i materialet. Det empiriska materialet har vissa begränsningar. Eftersom jag enbart studerat utredningar i ärenden med beslutade omhändertaganden kan analysen inte säga något om ärenden med annan åtgärd. Vidare kan det finnas

3 En utförligare presentation av undersökningens metod finns i Petersson (2003). 
annan information och andra beskrivningar av mödrar och fäder i socialtjänstens akter som inte kommer fram i utredningen. Det analysen säger något om är de uppgifter, beskrivningar och bedömningar som lagts fram av socialtjänsten inför beslut $i$ ärendena. Jag menar att det studerade materialet, just därför att det består av beslutsunderlagen, säger något om den syn på föräldraskap och de krav på föräldrars omsorg som finns inte bara inom socialtjänsten utan också bland dem som beslutar i dessa ärenden.

\section{Omsorg och föräldraskap}

Ett sätt att närma sig frågor om omsorgssvikt är att skilja mellan olika typer av omsorg. Swift (1995) skiljer med hänvisning till Gordon (1988) på tre olika former av omsorg. Den kan vara fysisk och handla om hemmiljön såsom städning och ordning i hemmet, men också avse barnets materiella utrustning samt omsorgen om dess hälsa. De andra formerna av omsorg gäller moralisk respektive emotionell omsorg. Med moralisk omsorg avses aspekter som har med barnens uppfostran och sedliga utveckling att göra. Emotionell omsorg avser barnens trygghet samt ömhet gentemot barnen och hänsynstaganden till deras känslor.

En viktig fråga för analysen av hur mödrar och fäder bedöms är - om föräldrarna inte bor tillsammans - var barnen bodde vid tillfället för omhändertagande, då det förefaller naturligt att den som haft den dagliga omvårdnaden om barnen granskas mera ingående än den andra föräld- ern. I materialet finns fyra ärenden i vilka barnet vid tillfället för omhändertagande bodde med båda sina biologiska föräldrar, tre syskongrupper samt ett ensamt barn som bodde växelvis hos både mor och far. Vidare finns två ärenden där barnet bodde hos fadern som ensam biologisk förälder: en flicka vars mor inte längre är i livet samt en pojke, som efter att modern intagits på behandlingshem, bodde en knapp månad hos fadern innan han blev omhändertagen. I 20 av de 26 ärendena bodde barnet således hos modern som ensam biologisk förälder. Det är också så att utredningarna i detta material i huvudsak uppehåller sig vid modern som förälder. Jag kommer därför att börja med en analys av hur mödrarna beskrivs och bedöms och därefter göra en jämförelse med vad som skrivs om fäderna. På så sätt kan också den fylligare bilden av mödrarna utgöra den kontrast gentemot vilken det blir tydligt vad som fattas i beskrivningen av fäderna.

\section{Mödrarna}

I 24 av de 25 ärenden där modern är i livet finns mer eller mindre utförliga beskrivningar av modern med avseende på utbildning, sysselsättning, boende, ekonomi och tidigare kontakter med socialtjänsten. Det finns också beskrivningar av hur modern är som mamma och hennes omsorg om barnen. Varje utredning avslutas med en sammanfattande bedömning och en vårdplan. Här beskrivs på vilka sätt modern brister i sin omsorg och vilka av barnets tidigare otillfredsställda behov som placeringen utanför hemmet skall uppfylla. 
De uppgifter som ligger till grund för bedömningen inhämtas på flera olika sätt och från flera olika källor. Det kan ske utifrån tidigare noteringar i socialtjänstens akter, genom socialtjänstens hembesök och samtal med barnen, men man samlar också in uppgifter från institutionella företrädare såsom skola, förskola, BVC och BUP. I vissa ärenden kontaktas också nära släktingar till barnen och i några fall även vänner och partners till föräldrarna. Den enskilda uppgiftslämnare som bidrar med mest stoff till utredningen är dock oftast modern själv, i 23 ärenden finns anteckningar från ett eller flera samtal med modern. Modern förväntas beskriva sina barn och sin egen relation till dem, samt hur hon ser på sig själv som mamma och sitt sätt att hantera de eventuella problem som barnen har. Hon får också redogöra för sin egen uppväxt, sin relation till barnens far och eventuell nuvarande partner.

Den fysiska omsorgen gäller som tidigare sagts den dagliga omvårdnaden om barnen och om hemmet. I 22 av de 25 ärendena är det denna typ av omsorg som står i fokus. Swift (1995) menar att utredningen och bedömningen av den fysiska omsorgen oftast koncentreras kring frågor om renlighet och ordning och att dessa faktorer dessutom tillmäts stor betydelse. I det här studerade materialet upptar dock sådana aspekter ett mycket litet utrymme i utredningarna, om de ens berörs, och det som granskas är i första hand den fysiska omsorg som rör barnen själva. Endast i två ärenden finns efter hembesök noteringar som har med hemmets renlighet och ordning att göra. I bägge fallen gäller det ärenden där bostaden måst totalrenoveras och saneras efter vräkning. Socialsekreteraren i det ena ärendet skriver efter hembesöket.

Vid ett hembesök kunde utredaren konstatera att lägenheten är mycket torftigt möblerad och för övrigt $i$ mycket dåligt skick, fast [namn på modern] bott där i endast en månad. Av det vi kan se ligger kattavföring på golvet som [namn på moder] bara har sopat undan. I [namn på barn]-s rum råder allmän kaos. Hela golvet är fullt med saker. Bord och stolar och andra möbler är mycket smutsiga.

Förutom i dessa två ärenden kommenteras inte mödrarnas omsorg om hemmet. När renlighet berörs gäller denna barnen, och man kommenterar t.ex. deras hygien. Viktiga uppgiftslämnare om den fysiska omsorgen är BVC-personal som kan berätta huruvida barnen är vaccinerade och om de tas med på kontroller och läkarbesök. Personal från skola och förskola får också lämna uppgifter om den fysiska omsorgen och det är de som i de flesta fall ger beskrivningar av hur väl barnen är utrustade materiellt, om de har hela och rena kläder liksom om deras kläder överensstämmer med väderlek och årstid. Här finns också beskrivningar av barn som inte har gymnastik- och badkläder med sig när sådana behövs. I detta tangerar de materiella aspekterna av den fysiska omvårdnaden den del av omsorgen som har med barnens ansvarstagande att göra. Barns ansvar för sig själva, för yngre syskon samt för hemmet i sin helhet beskrivs i utredningarna och $\mathrm{i}$ handläggarnas bedömningar. Om yngre barn lämnas ensamma - dagtid men framförallt nattetid eller under flera dygn - får dessa uppgifter en framträdande 
plats och ses som ett allvarligt tecken på sviktande omsorg. Här finns också beskrivningar av barn som själva tar ansvar för sin egen uppstigning, inte får någon frukost, går själva till skola eller förskola samt själva får klara av matinköp och inte får någon lagad mat $i$ hemmet. Förutom genom samtal med skol- och barnomsorgspersonal beskrivs barnens ansvarstagande respektive mödrarnas brister i ansvarstagande också genom anteckningar från hembesök. I ett ärende görs flera hembesök under en vecka, och den utredande tjänstemannen skriver efter det första:

Vid ombokat hembesök [datum] är de två yngsta barnen [namn på barnen] ensamma hemma. De ligger $i$ soffan och ser på TV. Barnen är oklädda och har inte ätit något under dagen. Ingen mat finns hemma. Enligt barnen är [namn på moder] hos en man hon umgås med när hon dricker. [namn på moder] har enligt barnen inte varit hemma under natten.

Barnens tillvaro utan vuxnas tillsyn, deras brist på mat och deras avsaknad av kläder återkommer sedan tre gånger $\mathrm{i}$ anteckningar från ytterligare hembesök. I detta ärende liksom i flera andra bildar noteringarna från hembesöken, tillsammans med andra uppgiftslämnares beskrivningar av den fysiska omsorgen, ett slags indiciekedja som visar på upprepade tillfällen av bristande omsorg. Genom framställningen, där enskilda men upprepade incidenter radas upp, konstrueras en bild av modern som kroniskt sviktande i sin omsorg - den bristande omsorgen blir ett tillstånd som bevisligen har pågått en tid och som med all sannolikhet kommer att fortgå. Detta sätt att skriva fram bristerna i moderns föräldraskap bidrar till att legitimera handläggarens bedömning och det föreslagna beslutet, eftersom det härigenom kan anses vila på en lång rad både konkreta och till synes objektiva bevis (jfr. Swift 1995). Denna bevisföring blir inte minst viktig i LVUärenden där barnen omhändertas utan föräldrarnas medgivande (jfr. Hollander 2001), men den kan också fungera som ett redskap för att övertyga modern om att ta emot den »hjälp« som socialtjänsten föreslår.

Den moraliska omsorgen om barnen tar upp betydligt mindre plats än den fysiska. I nio ärenden finns kommentarer kring denna typ av omsorg. Liksom i fråga om den fysiska omsorgen är skol- och barnomsorgspersonal viktiga uppgiftslämnare. Det är de som redogör för barnens vana att följa regler och respektera gränser. Indikatorer på bristande omsorg i de här fallen är till exempel: barn som har med sig kniv till skolan, inte kan ta tillsägelser, röker, skolkar, stjäl samt på andra sätt bryter mot institutionens regler. Här blir också mödrarnas egna berättelser en viktig del i belysningen av deras egen omsorgsbrist. Det är mödrar som omtalar att de har svårt att få barnen att lyda, som är rädda för barnens ilska och som låter barnen göra som de själva vill. Däremot finner vi inga kommentarer om moderns sedlighet eller moral, såvida det inte gäller missbruk. Om modern missbrukar i barnens närvaro eller om andra missbrukar och festar i hemmiljön noteras detta.

Den emotionella omsorgen om barnen upptar liksom den moraliska en mindre del i utredningarna. Det är också betydlig 
svårare att finna konkreta bevis för denna typ av omsorgssvikt jämfört med den fysiska, i synnerhet om man vill bygga upp en argumentation som kan rättfärdiggöra ett omhändertagande av barnen. Endast i fyra ärenden finns explicita noteringar om brister som har med den känslomässiga relationen mellan mor och barn att göra. Det är mödrar som inte kan ta till sig barnen, men det är också mödrar som binder sina barn alltför starkt till sig själva och där relationen beskrivs som "symbiotisk». Noteringar som implicit berör den emotionella omsorgen om barnen finns emellertid i nästan alla ärendena. I både vårdplaner och bedömningar omtalas mödrar som inte kan se barnens behov, eller som inte kan sätta barnens behov framför sina egna. Det finns också skrivningar som att placeringen skall erbjuda barnen en trygghet, stabilitet och förutsägbarhet som modern inte har möjlighet att ge dem. Likaså finns anteckningar om att barnen inte skall behöva oroa sig för modern. Vi kan här se en åtskillnad mellan å ena sidan en bristande omsorg i form av kärlek och ömhet gentemot barnen, å andra sidan en omsorgssvikt som snarare har att göra med förälderns egen emotionella utveckling och därav begränsade möjligheter att ta hänsyn till barnens känslor och behov. Det är i den senare betydelsen som den emotionella omsorgen om barnen tar det största utrymmet i utredningarna. Det tycks också som om bristerna i den fysiska och moraliska omsorgen antas ha sin grund i denna typ av känslomässig omsorg. Det emotionellt vuxna föräldraskapet ses som en förutsättning för ett $i$ andra avseenden gott föräldraskap.

Förutom de ovan berörda formerna av omsorgssvikt tas ytterligare en aspekt av mödrarnas omsorg upp i utredningarna. Denna gäller vad jag skulle vilja karaktärisera som social omsorg, en omsorg om barnets sociala kompetens samt möjligheten att erbjuda barnen en form av normalitet eller vanlighet $\mathrm{i}$ hemmiljö och andra sociala sammanhang. Här kommenteras moderns möjligheter att aktivera barnet och stimulera dess intellektuella och motoriska utveckling. I detta berörs också bristande sociala kontakter och isolering från moderns sida. Andra noteringar som har med denna typ av omsorg att göra gäller barn som inte har några leksaker eller bor i hem där man inte äter mat tillsammans och som måste få erfara "hur en vanlig familj fungerar".

Men det måste också tilläggas att utredningarna inte enbart innehåller uppgifter som pekar på brister i omsorgen. För alla de typer av omsorg som redovisas ovan finns också positiva kommentarer och uppgifter om god omsorg. Det är noteringar som att barnen är hela och rena, att modern tar dem med ut och aktiverar dem i naturen samt att mor och barn har en mnära och varm relation". Det finns heller inga direkt nedsättande beskrivningar av mödrarna som individer. Deras utseende, uppträdande eller moraliska vandel kommenteras i de flesta fall inte, vilket skiljer sig från de resultat som presenterats av Swift (1995) och Parton et al. (1997). Undantagen från denna regel utgörs av mödrar som uppträder berusade eller aggressiva vid möten med socialtjänsten eller när de lämnar och hämtar barn inom skola och barnomsorg. Genom det sociala arbetets professionalisering har föräldrarna allt mer kommit att beskrivas och granskas med hjälp av psy- 
kologiska termer och explicita moraliska omdömen är därmed sällsynta i dagens barnavårdsärenden (Lundström 1993, Egelund 1997). Trots denna professionella diskurs finns en underliggande moralitet som genomsyrar socialtjänstens praktik (Parton et al. 1997, Hall 1997, Egelund 2003). Bedömningen av föräldrarna vilar på normer för moder- och faderskap liksom på normer för hur familjer skall fungera. Implicit kan därför vissa moraliska omdömen utläsas. Till exempel finns anteckningar om mödrar som anses ha "övergivit barnen", och en mor som inte besöker skolans föräldramöten omskrivs som "ointresserad" av sitt barn. Dessa normer för vad som är ett vuxet eller gott föräldraskap synes inte vara könsneutrala, vilket framgår tydligt när vi jämför det som skrivs om mödrarna med det som noteras om fäderna och deras omsorg om barnen.

\section{Fäderna}

I materialet finns två ärenden i vilka fäderna inte nämns över huvudtaget, i sju ärenden finns knappa noteringar som att fadern är okänd eller avliden eller att han inte har någon kontakt med barnen. I 18 ärenden finns något mer utförliga noteringar om fäderna. Det kan handla om deras bostadsort, arbete, aggressivitet, missbruk, hälsotillstånd och kriminalitet. I de flesta ärendena finns också anteckningar om vilken kontakt de har med barnen samt hur de ser på barnets placering utanför hemmet. De noteringar som finns kring fädernas omsorg om barnen är dock så pass knapphändiga att analysen här måste göras utifrån andra frå- geställningar än de som användes i fråga om mödrarna. Fäderna är dessutom inte alltid tillgängliga för bedömning. I fyra ärenden är fadern avliden eller okänd. Av de 22 ärenden i vilka fadern är både känd och $\mathrm{i}$ livet finns sju ärenden i vilka barnet/en inte hade någon kontakt med fadern vid tillfället för omhändertagandet. I sex ärenden karaktäriseras kontakten som sporadisk eller icke fungerande, medan endast tre fäder av dem som inte bodde med sina barn sägs ha haft en regelbunden kontakt med barnet/en.

När det gäller socialtjänstens kontakter med fäderna finns noteringar från samtal med fadern i 16 ärenden. Det kan gälla både enstaka samtal per telefon eller mer återkommande kontakter vid möten med socialtjänsten. I de flesta av dessa ärenden finns anteckningar om hur fadern ställer sig till placeringen, tio fäder säger sig vara nöjda med barnens placering utanför hemmet medan tre motsätter sig densamma. I samband med fädernas ställningstaganden finns också anteckningar om hur de ser på omfattningen av sin egen kontakt med barnen samt på möjligheterna för dem själva att ha vårdnaden om barnen. Endast två fäder säger sig inte vilja ha något umgänge med barnen. I sju ärenden finns anteckningar om att fäderna uppger att de skulle vilja ha en mera regelbunden kontakt med barnen. Ingen fader ansåg dock att han vid den aktuella tidpunkten hade möjlighet att ta hand om barnen, även om fem av dem uttryckte att de själva önskade att de hade denna möjlighet. Några av de anledningar som fäderna, enligt utredningarna, uppger till att de inte kan ta hand om barnen är att: de har för liten lägenhet, de inte har ekonomiska möjligheter, de genomgår behandling eller vistas på anstalt 
samt att barnen skapar konflikter i deras nya familjer. Utifrån samtal med en av fäderna finns följande anteckning.

[Faderns namn] har sagt nej till att ta hand ombarnen när [moderns namn] legat inlagd på sjukhuset. Han har sagt att han absolut inte kan vara $i$ [namn på stad] då han är rädd att falla tillbaka $i$ sitt missbruk. Han arbetar fortfarande med sig själv och känner sig inte stabil nog att ta ett ansvar fullt ut som förälder. [Faderns namn] arbetar oregelbundna tider och bor i en etta som ytterligare skäl till att han inte kan ta hand om barnen. [Faderns namn] har sedan [moderns namn] blev sjuk velat att barnen ska fä flytta till ett familjehem. [Faderns namn] säger att han vill träffa barnen och att han tycker att det är viktigt att de kan ha regelbundet umgänge. Dock har det inte blivit så ofta.

Inte $\mathrm{i}$ någon utredning finns uppgift om någon far som uttryckligen säger att han ensam kan ta ansvar för barnen. I tre ärenden, alla avgjorda enligt LVU, finns dock noteringar om fäder som uttrycker en önskan att leva med barnen utan några förbehåll om varför det inte skulle vara möjligt. En far uppger enligt utredningen att han "skulle vilja leva med sin familj", en annan förstår inte varför barnet måste placeras. Den tredje fadern, som till skillnad från de två andra är ensamstående, menar att han möjligen, om han får en större lägenhet, skulle kunna ta hand om barnen under ett år medan modern går på behandling för sitt missbruk. Dock framför han detta på uppmaning av modern som vill undvika att barnen placeras i familjehem.

I 13 ärenden är faderns uppgifter om sina kontakter med barnet samt hans syn på omhändertagandet det enda som antecknas efter socialtjänstens samtal. I fyra utredningar talar fäderna även om barnens mor, de beskriver moderns uppväxt och de problem som hon har, till exempel i relation till barnen eller med missbruk och stökiga partners. Däremot finner vi inte någon far som redogör för sin egen uppväxt och relationen till sina egna föräldrar. Inte heller finns några beskrivningar av hur fäderna ser på de relationer som de haft eller för tillfället har med partners. Medan mödrarna får redogöra för sina svårigheter i relationen med barnen, såsom auktoritetsproblem och konflikter, finns det ingen far som talar om de svårigheter han upplever i relationen till sina barn. Det finns inga anteckningar om fäder som upplever att de har svårt att sätta gränser eller ta till sig barnen. Barnen berörs heller inte i någon större omfattning i de redovisningar som finns från samtal med fäderna. Dock finns ett ärende som utgör ett undantag i detta liksom i flera andra avseenden. Fadern som vårdas på behandlingshem träffar socialtjänstens utredare på hemmet. Han talar om sin nuvarande relation till barnen men också om hur det var när han själv levde tillsammans med barnen och deras mor. Detta samtal återges i utredningen som en berättelse som tar sin början när det äldsta barnet föds. Redogörelsen avslutas med faderns förhoppningar inför framtiden.

[Faderns namn] har för avsikt att vara en god förebild för sina barn, han önskar att de väljer ett liv skilt frain droger och kriminalitet men vet inte hur han ska skydda dem på bästa sätt. [Faderns namn] och [moderns namn] har för avsikt att begära gemensam 
vårdnad om [moderns namn] kan avstå från att missbruka. [Faderns namn] överväger annars att begära egen vårdnad.

Den utredande tjänstemannen noterar att fadern "talar varmt om barnen" och i den sammanfattning och bedömning som avslutar utredningen skrivs "samtidigt som placeringen fortgår kommer [moderns namn] och [faderns namn] att stöttas för att kunna upprätta ett gott föräldraskap». Även denna notering kan ses som unik. Endast i två andra utredningar innehåller vårdplanen något om stöd till fäder, och då i form av att båda föräldrarna behöver "stöttning i sitt föräldraskap« respektive hjälp för att »utvecklas i sin föräldraroll«. I bägge fallen handlar det om ärenden där barnen bott med båda sina föräldrar.

Eftersom det är så få barn som bott med sin far kan det ses som naturligt att färre ärenden innehåller anteckningar och omdömen om fadern i fråga om omsorg om barnen. Men inte ens i de ärenden där barnen bott med båda sina föräldrar omtalas faderns omsorg enskilt. Istället skrivs till exempel att "föräldrarna inte har förmågan att ge den omsorg och tillsyn som krävsu. Endast i det ärende där barnet bott hos fadern som ensam förälder och modern inte längre finns i livet, skrivs om något som har att göra med omsorg. I det här fallet är det den fysiska omsorgen som nämns. Det är barnet självt som berättar om hur hon får ta ansvar för städning och inköp. Någon beskrivning av fadern som förälder finns annars inte, varken från socialtjänstens hembesök, skola, kontaktfamilj eller någon annan uppgiftslämnare. Överhuvudtaget finns endast sparsamma kommentarer om fäderna från institutionella uppgiftslämnare, och de uppgifter som finns berör inte deras föräldraomsorger. Om den far som beskrivits som talande varmt om barnen, finns dock en anteckning från skolan. Fadern har där deltagit i ett föräldramöte och beskrivs av det ena barnets lärare som »en stabil förälder som visar att han bryr sig".

De övriga beskrivningar som rör fäderna, förutom de som handlar om hur ofta de har kontakt med barnen, är korta och tar upp negativa eller mindre smickrande beteenden och egenskaper hos fäderna. Det är t.ex. anteckningar om aggressivitet och våldsamhet, som att fadern misshandlat modern eller setts slå barnen. Det är fäder som av familjehemsföräldrar sägs vara onyktra vid umgängestillfällen eller som av personal på behandlingshem har upplevts som obehagliga och aggressiva. Swift (1995) menar att fäder enbart behandlas då de anklagas för något. Till viss del kan man säga att denna slutsats gäller även för det här studerade materialet, då de beskrivningar som finns av fäderna sällan innehåller uppgifter om något som kan tolkas som positivt i relation till deras föräldraskap.

Men beskrivningen av fäderna gäller sällan hur de är som föräldrar eller som omsorgsgivare. Vi finner inte, som när det gäller mödrarna, några beskrivningar av fädernas nära relation med sina barn eller berättelser om vad barnen gör tillsammans med fäderna. Ibland tycks det till och med som om fäderna inte räknas som tillhörande familjen. Även om det ofta finns anteckningar om att barnen behöver ha kontakt med båda föräldrarna för sin identitetsutveckling, finner vi lika ofta kommentarer 
som att "fadern har inte stött familjen". Familjen antas följaktligen bestå av mor och barn. Beskrivningarna av fäderna är således mycket fragmentariska och det mest slående är hur pass liten vikt som tycks läggas vid faderns föräldraskap när det gäller omsorg om barnen.

\section{Osynliga fäder och otillräckliga mödrar}

Med tanke på den asymmetri som finns i beskrivningarna av mödrar och fäder är det lätt att dra slutsatsen att omsorg om barnen är något som antas höra moderskapet till och att fäderna betraktas som marginaliserade både i relation till barnen och till familjen. Men samtidigt har vi i Sverige en familjepolitik som inriktar sig på jämställdhet mellan könen. Här poängteras barnens behov av båda sina föräldrar och vi premierar båda föräldrarnas deltagande i omsorgen om barnen (Andersson \& Hollander 1999).

Att politiska interventioner i praktiken får en annan utformning än den som var avsedd kan dock ses mera som regel än undantag (Kullberg 2004). Ett sätt att förstå varför det blir så är att utgå från ett så kallat nedifrån-och-upp perspektiv på offentlig förvaltning (Lipsky 1980, Johansson 1992), d v s att anta att det är i den tilllämpande praktiken som lagar och andra politiska interventioner får sin egentliga utformning. Förklaringen till detta läggs vid de betingelser under vilka det praktiska arbetet sker, såsom motstridiga krav och resursbrist. Jag kommer här att använda detta perspektiv för att diskutera de skilda sätt på vilka mödrar och fäder behandlas i utredningarna. Diskussionen tar fasta på tre aspekter: det sociala arbetets kunskapsbas, utredningarnas funktion i praktiken samt mödrarnas och fädernas agerande såsom det beskrivs i utredningarna.

\section{Det sociala arbetets kunskapsbas}

Det sociala arbetets professionalisering kan beskrivas som en övergång från moraliska bedömningsgrunder till kunskapsmässiga och teoretiska (Lundström 1993). De teoretiska kunskaper som åsyftas har sin grund $i$ en psykologisk diskurs och oftast en psykodynamisk teoribildning (ibid.). Men även om bedömningsgrunderna nu kan sägas vara förankrade i teoretisk kunskap är de för den skull inte könsneutrala, vilket visas av Swift (1995). Inom psykodynamisk teoribildning läggs fokus på moderns relation till barnen och det är främst moderns agerande som anses ha betydelse för barnets utveckling (ibid.). Mot bakgrund av denna kunskapsbas är det därför inte förvånande att mödrarna och mödrarnas relation till barnen granskas på ett annorlunda och mer utförligt sätt, än när det gäller fäderna.

Det psykodynamiska synsättet manifesteras också i den utförliga beskrivningen av mödrarnas uppväxt. Swift (1995) menar att det inom post-freudiansk diskurs finns ett antagande om att omsorgssvikt är ett cykliskt fenomen. Det anses vara något som går i arv och som reproduceras på mödernet i generation efter generation. Så beskrivs också mödrarnas uppväxt och deras relation till sina föräldrar ingående, och inte enbart utifrån samtal med mödrarna själva 
utan också med deras syskon samt tidigare och nuvarande partners. Även fadern blir en uppgiftslämnare som beskriver moderns uppväxt men inte sin egen.

Antagandet om att omsorgssvikt är ett cykliskt fenomen får i utredningstexten också en annan konsekvens. Det kan inte bara förklara moderns omsorgsvikt utan blir också ett sätt att definiera och kategorisera henne själv som förälder. Genom beskrivningar av hur modern som barn har särbehandlats av sin egen mor eller hur hon vuxit upp i ett hem med våld och missbruk, tillförs utredningen av hennes egna föräldraomsorger en ytterligare dimension. Framlyftandet av moderns problematiska uppväxt fungerar som ett redskap för att skriva fram och bevisa hennes egen omsorgssvikt (jfr. White 2003). Denna aspekt av den psykodynamiska kunskapsbasen framstår dock klarare i ljuset av den funktion som utredningstexten fyller.

\section{Utredningarnas funktion}

Utredningarna är till för att definiera och beskriva problem. Deras funktion i praktiken är att visa på att problemen i barnens hemmiljö eller hos dem själva är så stora att ett omhändertagande är befogat. De är som tidigare sagts till för att övertyga. I detta är utredningstexterna för sin dramaturgi beroende av vissa stereotypa intriger och karaktärer. Hilte (2000) menar att man i socialtjänstens utredningsarbete arbetar med könsspecifika typifieringar kring vilka man skapar en intrig för ärendet och genom denna definierar problemet. Två av de typifieringar som nämns av Hilte är den otillräckliga modern och den frånvarande fadern. Kanske är det just dessa intriger som färgar de beskrivningar som finns av mödrar och fäder i materialet. Moderns närvaro tas för given och behöver inte diskuteras medan faderns tillräcklighet i fråga om daglig omsorg aldrig behöver utredas. Lite tillspetsat kan man kanske formulera det som att fadern inte behöver problematiseras så länge han är tillräckligt frånvarande i relationen till barnen. Det är i ärenden där barnen bott med båda föräldrarna eller där fadern inte ställt sig positiv till placeringen som hans eventuella missbruk, kriminalitet och aggressivitet skrivs fram i utredningstexten. Jag menar därmed att föräldrarnas agerande kan bidra till en förståelse av varför de behandlas olika.

\section{Mödrars och fäders agerande}

I utredningarna framträder mödrar och fäder på olika sätt, framförallt i relationen till barnen men också i kontakterna med socialtjänsten. Fäderna gör inte anspråk på att själva kunna ta hand om barnen. De framhåller att de bryr sig om barnen och att de vill ha kontakt med dem, men de anser inte att de ensamma kan ha ansvar för dem. Den föräldraidentitet som fäderna enligt utredningarna tar på sig kan karaktäriseras med vad Slembrouck och Hall (2003) kallar caring but not coping. Det vill säga en förälder som bryr sig om men som inte klarar av den dagliga omvårdnaden om barnen. I detta intar de också en föräldraidentitet som innebär en moraliskt legitim position (ibid.). De kan framstå som goda föräldrar trots att de inte kan vara föräldrar fullt ut 
och deras agerande tolkas inte som att de överger barnen.

Genom att vara positiva till de åtgärder som socialtjänsten föreslår intar de också en viss klientposition. De framträder på ett sätt som vissa forskare menar karaktäriserar den för socialtjänsten goda klienten. Den goda klienten är en klient som inser behovet av den hjälp som socialtjänsten erbjuder samtidigt som hon/han inte kritiserar eller ifrågasätter handläggarens bedömning och kunskap (Juhila 2003). Enär fäderna så tydligt själva intar denna position, behöver de heller inte granskas vidare i utredningen. Varken fadern eller beslutsfattarna behöver övertygas om att han inte utgör ett alternativ till placering av barnen.

Eftersom mödrarna ofta har en annan relation till barnen blir deras förhållande till socialtjänsten också ett annat - det är ju deras föräldraomsorger som ifrågasätts. För att barnen skall placeras på frivillig väg krävs att föräldrarna godkänner hela den vårdplan som handläggaren upprättar. Detta innebär att modern måste erkänna sitt tillkortakommande som förälder. De mödrar som skriver under vårdplanen och som i detta uppträder som goda klienter beskrivs i utredningarna som »kloka och insiktsfulla» eller som "mogna». I detta fungerar vårdplanen inte bara som ett kontrakt mellan modern och socialtjänsten utan den blir också ett slags syndabekännelse. Modern erkänner sina brister som förälder och får i utbyte för denna bekännelse upprättelse i det att hon nu kan tillskrivas identiteten som en mogen och vuxen förälder.

Men i materialet finns också mödrar vilkas agerande inte alls överensstämmer med den goda klientens. Det är mödrar som vilseleder socialtjänsten, som ljuger om sitt missbruk och som rymmer med barnen. I dessa fall behövs en helt annan typ av övertygande text i beslutsunderlaget (jfr. Hall 1997). Här fyller det tidigare omtalade uppräknandet av incidenter en funktion för att etablera en bild av kronisk omsorgssvikt och beskrivningen av moderns uppväxt blir ett sätt att definiera hennes möjligheter att vara förälder.

\section{Slutord}

Jag menar att dessa tre aspekter tillsammans bidrar till att mödrar och fäder behandlas på skilda sätt i utredningstexterna. Det sociala arbetets kunskapsbas riktar uppmärksamheten mot mödrarna och deras relation till barnen. Föräldrarnas olika relation till barnen och deras skilda sätt att agera i förhållande till socialtjänsten, i kombination med utredningstexternas funktion att övertyga, gör att det blir viktigare att granska och problematisera modern.

Men det finns samtidigt en dubbelhet i det sätt på vilket man i utredningarna hänvisar till begrepp som familj och föräldraskap. Det synes som om man opererar med två olika familjebegrepp. Å ena sidan finner vi en implicit och praktisk bestämning av familjen där den otillräckliga modern och den frånvarande fadern passar väl in som stereotyper. Familjen antas här bestå av mor och barn och fadern medräknas bara undantagsvis. Det finns också andra förväntningar på moderns föräldraskap och hennes omsorg om barnen. Utifrån denna syn på föräldraskap blir en fars närvaro på ett föräldramöte en händelse som är värd att notera och vilken dessutom gör att han 
kan beskrivas som en "stabil förälder". När det gäller en mor är det istället hennes frånvaro från samma typ av möten som noteras, och denna tolkas som ett "ointresse" för barnen. En far utan kontakt med sina barn karaktäriseras som att han inte har "stött familjen" medan en mor i samma situation sägs ha "övergivit barnen".

Å andra sidan finner vi även en helt annan syn på familjen, där båda föräldrarna är lika viktiga och där föräldrarna har ett gemensamt ansvar för barnen även om de inte lever i en kärnfamilj. Detta familjebegrepp och denna syn på föräldraskap överensstämmer mera med de politiska idealen. Emellertid framstår det även i utredningarna mera som ett ideal än en realitet, då det kommer till uttryck $\mathrm{i}$ vårdplaner och bedömningar. Här finner vi formuleringar som att barnet »behöver båda sina föräldrar för sin identitetsutveckling» eller att "båda föräldrarna behöver stöttning i sitt föräldraskap«.

Som framgår av resonemanget ovan används de båda familjebegreppen i olika faser av utredningstexten. Bilden av den splittrade familjen, där föräldraskapet upprätthålls av en mor, är till för att definiera problemet. Den visar på den sviktande omsorgen och på omhändertagandets nödvändighet. Bilden av det gemensamma föräldraskapet, där båda föräldrarna är lika viktiga, är framförallt retorisk. Den definierar den norm från vilken den nuvarande situationen avviker, men den bidrar också, genom att visa på hur socialtjänstens arbete kommer att bidra till upprättande av normen, till att legitimera den föreslagna insatsen.

\section{Referenser}

Andersson, Gunvor \& Hollander, Anna (1999) „Om barns rätt och barns bästa巛i Andersson, G. et al. Barnet $i$ den sociala barnavården. Centrum för utvärdering av socialt arbete. Stockholm: Liber.

Bangura Arvidsson, Maria (2003) Ifrågasatta fäder. Olika bilder av fäder till socialt utsatta barn. Lund: Lund Dissertations in Social Work 13.

Egelund, Tine (1997) Beskyttelse af barndommen. Socialforvaltningers risikovurdering og ingreb. København: Hans Reitzels Forlag.

Egelund, Tine (2003) „'Farlige' forældre: Den institutionelle konstruktion af dem, der afviger fra os« i Järvinen, M. \& N. Mik-Meyer (red.) At skabe en klient. Institutionelle identiteter $i$ socialt arbejde. København: Hans Reitzels Förlag.

Ericsson, Kjersti (1996) Barnevern som samfunnsspeil. Oslo: Pax Forlag.

Gordon, Linda (1988) Heroes of their own lives. The politics and history of family violence. London: Virago Press.
Hall, Christopher (1997) Social Work as Narrative. Storytelling and persuasion in professional texts. Aldershot: Ashgate.

Hilte, Mats (2000) Förändring och kön i socialt arbete. En narrativ analys av en människobehandlande organisation. Lund: Meddelanden från socialhögskolan 2000:4.

Hollander, Anna (2001) „En mammas motstånd - om samtycke vid ett omhändertagande« $\mathrm{i}$ Andersson, G. (red) Haverier i social barnavård? Fem fallstudier. Centrum för utvärdering av socialt arbete. Stockholm: Gothia.

Johansson, Roine (1992) Vid byråkratins gränser. Omhandlingsfrihetensorganisatoriskabegränsningar i klientrelaterat arbete. Lund: Arkiv.

Juhila, Kirsi (2003) „Creating a 'Bad' Client. Disalignment of Institutional Identities in Social Work Interaction«. i Hall, C. (Eds) Constructing Clienthood in Social Work and Human Services. Interaction, Identities and Practices. London: 
Jessica Kingsley Publishers.

Kullberg, Christian (2004) "Work and Social Support: Social Workers' Assessments of Male and Female Clients' Problems and Needs" AFFILIA, 19 (2), s. 199-210.

Lipsky, Michael (1980) Street-Level Bureaucracy. Dilemmas of the Individual in Public Services. New York: Sage.

Loseke, Donileen R. (1999) Thinking about Social Problems. An Introduction to Constructionist Perspectives. New York: Aldine de Gruyter.

Lundström, Tommy (1993) Tvångsomhändertagande av barn. En studie av lagarna, professionerna och praktiken under 1900-talet. Rapport i socialt arbete $\mathrm{nr}$ 61-1993. Stockholms universitet, Socialhögskolan.

Parton Nigel, David Thorpe \& Corinne Wattam (1997) Child Protection. Risk and the Moral order. Basingstoke: Macmillan Press.

Petersson, Gunilla (2003) „Med hänsyn till barnets vilja? Socialtjänstlagens barnperspektiv och den nya välfärdsstatens villkor« i Sandin, B. \& G. Halldén (red) Barnets bästa. En antologi om barndomens innebörder och välfärdens organisering. Stockholm: Symposion.

Slembruck, Stef \& Hall, Christopher (2003) „Caring but Not Coping. Fashioning a Legiti- mate Parent Identity" i Hall, C. (Ed) Constructing Clienthood in Social Work and Human Services. Interaction, Identities and Practices. London: Jessica Kingsley Publishers.

Sundell, Knut \& Alldahl, Margareta (1993) Att inte räcka till som mamma: hur ser omsorgssvikande och icke-omsorgssviktande mammor på sitt föräldraskap. Stockholms socialtjänsts Forsknings- och Utvecklingsbyrå. FoU-rapport 1993:18

Sundell, Knut \& Karlsson, Ulf (1999) Social barnavård i tio svenska kommuner. Vilka barn berörs, hur utreds de och vad händer med dem? Stockholm: Socialförvaltningen, Forsknings- och utvecklingsenheten. FoU-rapport 1999:26.

Swift, Karen J. (1995) Manufacturing 'Bad Mothers': A Critical Perspective on Child Neglect. Toronto: The University of Toronto Press.

Turney, Danielle (2000) »The Feminizing of Neglect". Child and Family Social Work, 5 s. 47-56.

White, Sue (2003) »The Social Worker as Moral Judge. Blame, Responsibility and Case Formulation." i Hall, C. (Eds) Constructing Clienthood in Social Work and Human Services. Interaction, Identities and Practices. London: Jessica Kingsley Publishers.

\section{Summary}

\section{Present mothers and sufficiently absent fathers: Social service assessments of mothers and fathers as care-givers.}

This article focuses upon how mothers and fathers as care-givers are scrutinized and assessed by the social services in cases of neglect, and analyses why the parents are treated differently. The empirical material consists of written reports from 26 cases were children have been placed in foster care.
Three features of social service practice are used to understand the different ways in which mothers and fathers are assessed: the knowledge base of social work; the function of the written report in working practice; and the different conduct of mothers and fathers in relation to the social service. 